Original Research Paper

\title{
Pemanfaatan Teknologi Budikdamber (Budidaya Ikan di dalam Ember) Sebagai Model Urban Farming Berkelanjutan
}

\author{
Andre Rachmat Scabra ${ }^{1 *}$, Muhammad Marzuki², Bagus Dwi Hari Setyono², Laily Fitriani \\ Mulyani ${ }^{1}$ \\ ${ }^{1}$ Program Studi Budidaya Perairan Universitas Mataram Universitas Mataram, Mataram, Indonesia; \\ ${ }^{2}$ Program Studi Budidaya Perikanan, Program Vokasi Unram (PDD) di Kabupaten Lombok Utara
}

https://doi.org/10.29303/jpmpi.v3i2.1120

Sitasi: Scarba, A. R., Marzuki, M., Setyono, B. D. H \& Mulyani, L. F. (2022). Pemanfaatan Teknologi Budikdamber (Budidaya Ikan di dalam Ember) Sebagai Model Urban Farming Berkelanjutan. Jurnal Pengabdian Magister Pendidikan IPA, 5(1)

\section{Article history}

Received: 11 Januari 2022

Revised: 01 Februari 2022

Accepted: 07 Februari 2022

*Corresponding Author:

Andre Rachmat Scabra, Program Studi Budidaya

Perairan Universitas

Mataram Universitas

Mataram, Mataram,

Indonesia;

Email:

andrescabra@unram.ac.id

\begin{abstract}
Abstrak: Ikan merupakan bahan pangan yang berkualitas tinggi dan sangat bermanfaat bagi kesehatan tubuh. Berbagai manfaat dari daging ikan hanya akan diperoleh apabila ikan yang dikonsumsi berada dalam keadaan segar. Dalam kondisi yang tidak segar (busuk), kandungan gizi yang ada pada daging ikan menjadi rusak. Salah satu upaya yang dapat dilakukan agar konsumsi ikan segar dapat dilakukan secara kontinyue adalah dengan melakukan kegiatan urban farming, yaitu budidaya ikan dalam ember (budikdamber). Kegiatan pengabdian kepada masyarakat ini bertujuan untuk meningkatkan pengetahuan dan memberikan bimbingan tekhnis kepada mitra yang terlibat dalam hal aplikasi tekhnologi budidaya ikan dalam ember. Kegiatan pengabdian kepada masyarakat ini dilakukan melalui berbagai metode kegiatan yang tersusun secara terstruktur yaitu survei lokasi, penyusunan materi sosialisasi dan bimbingan tekhnis kegiatan, pembentukan model teknologi, pendampingan pelaksanaan tekhnis, dan evaluasi. Kegiatan dilaksanakan pada kelompok pemuda Jangkar Ampenan yang berlokasi di Lingkungan Tangsi, Kecamatan Ampenan Selatan, Kota Mataram. Materi yang disampaikan saat kegiatan berlangsung meliputi persiapan (alat, bahan, metode kerja), tekhnis perakitan perangkat budidaya ikan, manajemen pemberian pakan, manajemen kualitas air, dan manajemen panen. Alat dan bahan yang diperlukan dalam kegiatan ini meliputi ember berkapasitas 150 liter, ikan lele berukuran 5-7 g/ekor, pakan ikan lele komersil, bibit kangkung, pipa, kawat, gelas plastik berukuran $200 \mathrm{ml}$, bor dan grinda, seser, dan aerator. Berdasarakan kegiatan yang telah dilakukan, kesimpulan dari kegiatan pengabdian kepada masyarakat ini adalah telah disampaikannya informasi, pengetahuan, dan bimbingan tekhnis kepada mitra tentang tekhnologi budidaya ikan dalam ember (budikdamber).
\end{abstract}

Keywords: Urban Farming, Budikdamber, Ikan Lele, Lingkungan Tangsi, Kecamatan Ampenan.

bahwa ikan memiliki berbagai kandungan gizi seperti protein yang berperan dalam pertumbuhan, asam lemak omega 3 (EVA) dan 6 (DHA) yang berperan dalam pembentukan dan perkembangan otak, serta berbagai mineral yang berperan dalam perkembangan janin pada ibu hamil. Mengonsumsi berkualitas tinggi dan sangat bermanfaat bagi kesehatan tubuh. Astisela (2019) menyatakan 
ikan yang mengandung minyak ikan tinggi (omega3), dapat menurunkan risiko penyakit kardiovaskular, dan stroke. Selain itu, mengonsumsi makanan yang kaya asam lemak omega-3 secara rutin dapat mengurangi kadar trigliserida (lemak jahat) dalam darah. Khusus pada Ikan laut, Inara (2020) menyatakan bahwa kandungan gizinya mampu mencegah dan menjaga kesehatan tubuh seperti mencegah penyakit jantung, menjaga fungsi dan kesehatan otak, mendukung kesehatan jantung, mencegah kerusakan tiroid dan menjaga kesehatan mata.

Berbagai manfaat dari daging ikan hanya akan diperoleh apabila ikan yang dikonsumsi berada dalam keadaan segar. Dalam kondisi yang tidak segar (busuk), kandungan gizi yang ada pada daging ikan menjadi rusak sehingga tidak menjadi bahan yang bermanfaat bagi tubuh. Ikan yang busuk tidak akan bermanfaat bagi tubuh, bahkan sebaliknya akan menyebabkan berbagai macam permasalahan bagi kesehatan. Milo (2013) memberikan informasi bahwa Dalam sebuah penelitian yang dilakukan oleh FDA terhadap sampel dari makanan laut (ikan), 86\% yang diperiksa mengandung hasil positif untuk bakteri jenis Vibrio parahaemolyticus. Widowati (2008) menyatakan bahwa salah satu jenis bakteri yang hidup di laut dan bersifat sebagai patogen dari marga Vibrio adalah Vibrio parahaemolyticus. Jenis bakteri tersebut berbahaya bagi kesehatan manusia.

Ikan segar dapat diartikan sebagai ikan yang dikonsumsi dalam jangka waktu yang relatif berkisar antara 6 - 7 jam setelah ikan tersebut mengalami kematian pada masa panen. Suprayitno (2020) menyatakan bahwa perubahan yang dialami oleh ikan setelah fase kematian berlangsung dalam tiga tahapan, yaitu pre-rigor mortis, rigor mortis, dan post-rigor mortis. Perubahan setiap tahapan ini dapat digunakan sebagai indikator perubahan kualitas ikan. Pada tahap pre rigor mortis, ikan masih dianggap segar karena sifat ikan hidup masih melekat, yaitu daging yang kenyal, mata yang jerih, dan insang yang merah menyala. Pada tahap ini (pre rigor mortis), daging ikan tidak mengeluarkan bau dari cairan tubuhnya serta pHnya mendekati netral. Apabila mendapat tekanan, sifat daging ikan masih elastis sehingga akan kembali ke bentuk semula. Pada tahap rigor mortis, tekstur daging ikan yang kenyal dan elastis pada tahap pre rigor mortis akan berubaah secara bertahap menjadi kaku, keras dan kehilangan kelenturanya. Hal tersebut terjadi karena aktifitas aktin dan miosin. Tahap rigor mortis merupakan tahap akhir daging ikan dikatakan masih segar.

Daging ikan memiliki karakter yang berbeda dengan daging hewan ternak lainnya seperti sapi, kambing, ayam, atau domba. Daging ikan perlu ditangani dengan baik agar manfaatnya dapat diperoleh secara maksimal. Absorpsi proteinnya pada daging ikan lebih tinggi dibandingkan dengan daging hewan lain seperti ayam dan sapi. Daging ikan mempunyai serat-serat protein lebih pendek dari pada serat serat protein daging sapi atau ayam (Inara, 2020). Produk perikanan memiliki sifat sangat mudah rusak/busuk. Hal ini terjadi karena adanya aktivitas enzim, mikroorganisme atau oksidasi oksigen.

Konsumsi daging ikan segar harus diupayakan agar seluruh manfaat yang ada pada daging tersebut dapat diperoleh. Beberapa upaya yang dapat dilakukan antara lain; mengenali ciriciri ikan segar dan ikan tidak segar, membeli langsung dari produsen di kolam ikan, dan melakukan aktifitas budidaya ikan secara mandiri. Salah satu upaya produksi ikan yang dapat dilakukan dengan mudah adalah kegiatan urban farming, yaitu budidaya ikan dalam ember (budikdamber).

Budidaya ikan dalam ember (budikdamber) merupakan aktifitas produksi ikan yang sangat memungkinkan untuk dapat dilakukan baik oleh masyarakat perikanan yang berpengalaman, maupun masyarakat awam yag belum pernah melakukan kegiatan budidaya sebelumnya. Hal tersebut karena minimnya volume media budidaya pada wadah yang menggunakan ember. Sebuah ember yang berukuran besar hanya mampu menampung air dengan kapasitas volume 120 liter. Pada volume tersebut, Scabra et al., (2021), menyatakan bahwa ikan lele mampu diproduksi dengan padat penebaran 100 ekor.

Habiburrohman (2018), menyatakan bahwa kegiatan budidaya ikan di dalam ember (budikdamber) adalah hemat air, zero waste, perawatan mudah, dan dapat dilakukan secara alamiah tanpa menggunakan bahan kimia. Penggunaan wadah berupa ember menjadi suatu hal yang sangat menarik dan mencirikan bahwa kegiatan ini dilakukan pada lahan yang terbatas. Wadah ember dapat dengan mudah dipindahkan (bersifat sementara) dan dapat diletakkan pada 
luasan lahan yang tersedia. Pemanfaatan lahan yang sangat minim dengan hanya menggunakan ember diharapkan dapat menjadi solusi alteraif dalam kegiatan budidaya ikan yang bisa dilakukan oleh semua orang di pekarangan rumah masing-masing.

Kegiatan pengabdian kepada masyarakat ini bertujuan untuk meningkatkan pengetahuan dan memberikan bimbingan tekhnis kepada mitra yang terlibat dalam hal aplikasi tekhnologi budidaya ikan dalam ember. Kegiatan ini diharapkan dapat bermanfaat sebagai informasi dalam kegiatan urban farming, yaitu agar diperolehnya kapasitas panen ikan yang maksimal meskpiun hanya dilakukan pada lahan sempit berupa wadah ember. Produksi ikan yang dilakukan secara mandiri diharapkan menjadi sarana dalam terwujudnya konsumsi ikan segar yang mengandung gizi yang baik (tidak rusak).

\section{Metode}

Kegiatan pengabdian kepada masyarakat ini dilakukan melalui berbagai kegiatan yang tersusun secara terstruktur. Penyusunan kegiatan ini didasarkan pada hasil korrdinasi dan konsultasi antara seluruh tim pelaksana kegiatan. Metode yang telah disepakati bersama tersebut antara lain sebagai berikut:

\section{Survei lokasi}

Survei awal pada lokasi pelaksanaan kegiatan diperlukan untuk mengetahui kondisi nyata para pembudidaya ikan. Kegiatan survei menjadi hal yang mutlak dilakukan agar kegiatan dapat berlangsung dengan baik, yaitu mencapai nilai efektifitas yang tinggi. Survei awal juga menjadi moment untuk mengenal lebih dekat para pengelola (masyarakat) kolam ikan, dan stakeholder tarkait seperti perangkat desa atau pemerintah daerah pada lokasi tempat pelaksanaan kegiatan.

2. Penyusunan materi sosialisasi dan bimbingan tekhnis kegiatan

Materi sosialisasi disusun berdasarkan penelaahan pada permasalahan yang terjadi pada masyarakat. Materi yang disampaikan disusun dengan baik, yaitu disesuaikan dalam penyampaiannya agar mudah difahami oleh kelompok masyarakat yang tergolong awam. Pelaksanaan sosialisai direncanakan tidak hanya melibatkan kelompok masyarakat pembudidaya ikan saja, tetapi juga stakeholder terkait seperti perangkat desa dan pemerintah (dinas) terkait.

3. Pembentukan model teknologi

Kegiatan pengabdian kepada masyarakat ini ditargetkan dapat memberikan paket bantuan kepada mitra terkait. Pembentukan model teknologi didasarkan atas pengalaman tim pelaksana dalam mengelola kolam budidaya ikan yang terstandar. Instalasi paket teknologi tersebut akan dilakukan oleh tim pelaksana kegiatan, sementara operasionalnya akan dikelola oleh mitra.

4. Pendampingan pelaksanaan tekhnis

Dalam rangka mensukseskan kegiatan pengabdian kepada masyarakat, pendampingan secara rutin akan dilakukan oleh tim pelaksana. Selama kegiatan berlangsung, yaitu dalam jangka waktu 6 bulan, kegiatan pendampingan ditargetkan dilakukan sekurang-kurangnya 6 kali. Pendampingan yang lebih intensif dapat saja terjadwalkan apabila terjadi kondisi khusus yang memerlukan penanganan lebih mendalam.

5. Evaluasi

Evaluasi dilakukan secara bertahap, yaitu pada masa awal, pertengahan, dan akhir kegiatan. Evaluasi total dilakukan pada masa akhir. Target utama evaluasi adalah hasil produksi ikan pada lahan sempit yang dilakukan oleh mitra. Apabila nilai produksi meningkat, maka teknologi ini dapat direkomendasikan untuk diterapkan lebih lanjut. Pelaksanaan tekhnis juga perlu dievaluasi dan diharapkan dapat menjadi saran atau rujukan dalam rangka pengembangan teknologi yang lebih baik.

\section{Hasil dan Pembahasan}

Kegiatan pengabdian kepada masyarakat ini dilaksanakan pada kelompok pemuda Jangkar Ampenan yang berlokasi di Lingkungan Tangsi, Kecamatan Ampenan Selatan, Kota Mataram, Provinsi Nusa Tenggara Barat. Lokasi ini dinilai cocok untuk melaksanakan kegiatan terkait karena memenuhi beberapa poin kriteria yang telah ditetapkan, yaitu : merupakan kawasan padat penduduk dengan rumah/hunian minimalis yang memiliki luasan pekarangan yang minim dan keadaan sosial masyarakat nya yang memiliki kegiatan utama (pekerjaan pokok) selain sebagai 
pembudidaya ikan. Lingkungan padat penduduk dengan luasan pekarangan yang sempit sangat cocok menjadi lokasi kegiatan budidaya ikan dalam ember. Sebagaimana yang disampaikan oleh Scabra et al., (2021), wadah ember menjadi alternatif yang dapat digunakan untuk kegiatan budidaya ikan bagi masyarakat yang memiliki lahan sempit. Masyarakat yang tidak menjadikan kegiatan budikdamber ini sebagai lapangan pekerjaan utama juga menjadi kriteria utama karena kegiatan budikdamber ini diharapkan dapat menjadi kegiatan yang bersifat tambahan. Efisiensi produksi ikan dapat dengan mudah didapatkan karena pengelolaannya cenderung lebih mudah dan minimnya alokasi waktu yang dibutuhkan dalam pengelolaan.

Untuk menunjang keberhasilkan kegiatan, tim pelaksana kegiatan menyiapkan berbagai materi yang diperlukan. Materi tersebut merupakan intisari keilmuan pada program studi budidaya perairan yang tertuang pada mata kuliah tekhnologi budidaya ikan air tawar. Penyajian dan penyampaian materi terkait dilakukan dengan sederhana agar dapat difahami dan diaplikasikan oleh masyarkaat yang awam tentang kegiatan budidaya ikan. Materi yang disampaikan saat kegiatan berlangsung meliputi persiapan (alat, bahan, metode kerja), tekhnis perakitan perangkat budidaya ikan, manajemen pemberian pakan, manajemen kualitas air, dan panen.

Alat dan bahan yang diperlukan dalam kegiatan ini meliputi ember, ikan, pakan ikan, bibit kangkung, pipa, kawat, gelas plastik, bor dan grinda, seser, aerator, dll. Ember yang digunakan adalah ember berkapasitas 150 liter. Dalam aplikasinya, kapasitas ember yang bisa digunakan sangat bervariasi. Berbagai kegiatan serupa pernah dilakukan dengan menggunakan ember berkapasitas 100, 80, atau bahkan 60 liter. Nursandi (2018) melakukan kegiatan budidaya ikan lele di dalam ember berkapasitas 60 liter. Dalam kondisi yang baru, ember sebaiknya dicuci hingga bersih sehingga tidak menyisakan bau plastik sama sekali. Sisa plastik yang berbau dapat menjadi racun yang dapat menyebabkan kematian pada ikan yang dipelihara. Proses perakitan unit ember yang akan digunakan sebagai sarana budidaya ikan dapat dilihat pada Gambar 1.

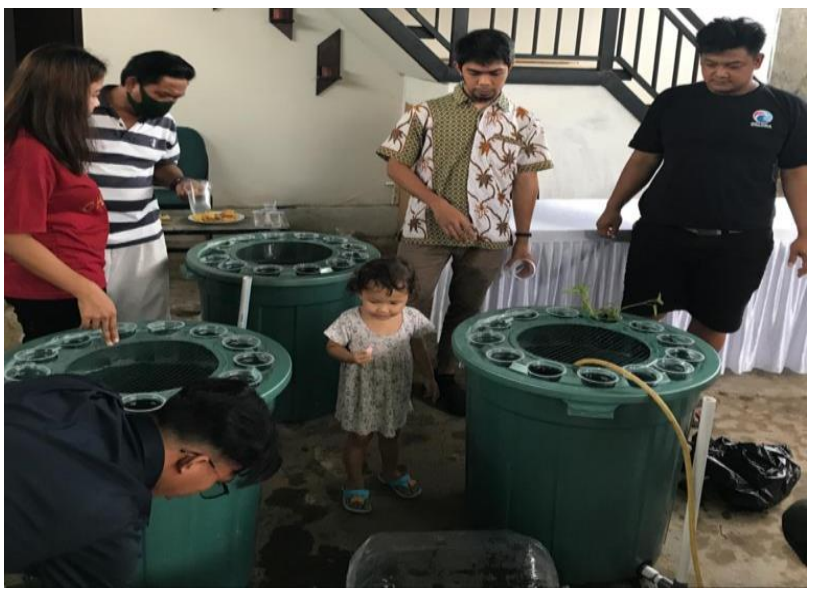

Gambar 1. Proses perakitan wadah ember menjadi fasilitas budidaya ikan

Ikan yang digunakan pada kegiatan ini adalah ikan lele (Clarias Gariepinus) yang didapatkan dari Balai Benih Ikan Batu Kumbung, Lingsar. Ikan lele dipilih karena sifatnya yang cenderung lebih mudah dipelihara dibandingkan dengan jenis ikan yang lain. ikan lele juga memiliki kadar nutrisi yang cukup baik. Ubadillah dan Hersoelistyorini (2010), menyatakan bahwa ikan lele dumbo merupakan jenis ikan yang cenderung mudah diterima oleh masyarakat luas karena memiliki banyak kelebihan yaitu pertumbuhannya cepat, memiliki kemampuan adaptasi terhadap lingkungan yang baik, memiliki rasa yang enak, kandungan gizinya tinggi, dan harganya lebih terjangkau.

Pakan yang digunakan adalah pakan ikan lele komersil dengan kandungan protein berkisar antara 31-33 \%, lemak 3-5 \%, serat 4-6\%, kadar abu $10-13 \%$, dan kadar air 11-13\%. Jenis pakan ini dipilih karena kemudahan dalam mendapatkannya. Pakan jenis ini juga telah terstandart dan banyak digunakan dalam kegiatan budidaya ikan lele. Harga pakan ini berkisar antara 10-11 ribu per kilogram.

Jumlah pemberian pakan yang digunakan adalah $3 \%$ dari biomass ikan lele. Jumlah tersebut dipilih agar kualitas air pada fasilitas budidaya yang dikelola tidak cepat mengalami kerusakan. Scabra dan Setyowati (2019) menyatakan bahwa terdapat dua metode dlaam pemberian pakan yang dilihat dari sisi pertumbuhan dan kualitas air media budidaya. Pakan yang diberikan pada jumlah yang banyak (maksimal) dapat menyebabkan pertumbuhan ikan menjadi lebih maksimal. Di sisi yang lain, dampak negatif yang akan terjadi adalah kualitas air media budidaya menjadi lebih cepat 
rusak akibat limbah-limbah sisa metabolisme. Sebaliknya, pada pemberian jumlah pakan yang minim, pertumbuhan ikan terjadi secara lambat, akan tetapi kualitas air dapat lebih bertahan baik dalam jangka waktu yang lebih lama. Diantara dua pilihan metode pemberian pakan tersebut, pilihan kedua lebih diutamakan karena waktu panen bukanlah suatu hal yang urgent pada kegiatan ini. Karimah et al., (2018), juga menjelaskan bahwa jumlah pakan yang diberikan pada kegiatan budidaya ikan berkaitan dengan ukuran bobot dari ikan. Jumlah pemberikan pakan ikan yang benar dapat memaksimalkan pemanfaatan pakan oleh ikan sehingga pertumbuhan ikan menjadi maksimal, biaya operasional berkurang, dan kualitas air dapat terjaga dalam waktu yang lebih lama.

Frekuensi pemberikan pakan adalah 3 kali hari, yaitu pada pukul 07.00, 14.00, dan 21.00. Hal tersebut menjelaskan bahwa setiap pemberian pakan, jumlah yang diberikan adalah $1 \%$. Jumlah pakan yang diberikan pada setiap kali pemberian tidak boleh terlalu banyak. Hal tersebut karena ikan memeiliki kapasitas daya tampung pakan pada lambung yang terbatas. Jumlah pakan yang berlebih menyebabkan pakan tidak akan termakan, seingga akan terbuang ke perairan yang pada akhirnya akan berujung pada rusaknya kualitas air. Pakan yang diberikan juga tidak boleh terlalau sedikit karen ahal tersebut menyebabkan pertumbuhan ikan mnjadi lambat. Tahaparih dan Suhenda (2009), menyatakan bahwa pada aktifitas pemeliharaan ikan, frekuensi pemberian pakan perlu mendapatkan perhatian yang serius karena akan mempengaruhi jumlah pakan yang dikonsumsi, tingkat efisiensi pakan dan kemungkinan rusaknya lingkungan atau media budidaya. Ruskanya media budidaua ikan dapat menyebabkan kesehatan dan kelangsungan hidup ikan terganggu.

Pipa berukuran 1 inch digunakan untuk keperluan pergantian air. Bagian dasar ember dilubangi dan disambungkan dengan pipa yang menjulur pada bagian luar ember. Pipa tersebut juga berfungsi sebagai pengontrol ketinggian air pada wadah ember. Apabila pipa tersebut dimiringkan, maka air pada wadah ember akan keluar secara gravitasi sesuai dengan hukum archimedes. Pada bagian dalam ember, pipa pembuangan tersebut terkoneksi degnan pipa panjang yang telah dilubangi pada berbagai sudut pipa/. Hal tersebut menyebabkan kotoran/limbah ikan di seluruh luasan dasar ember dapat terjangkau dan tersedot pada saat dilakukan pergantian air.

Pergantian air dilakukan 1 kali dalam kurun waktu yang berkisar antara 2-5 hari. Pada masa awal pemeliharaan ikan, yaitu ketika ikan masih berukuran kecil $(5-7 \mathrm{~cm})$, pergantian air dilakukan dalam kurun waktu yang lebih lama. Sebaliknya, pada masa akhir pemeliharaan ikan, yaitu ketika ikan telah berukuran besar, ritme pergantian air dilakukan dalam kurun waktu yang lebih singkat. Hal tersebut berbanding lurus dengan jumlah pakan yang diberikan sebagaimana yang telah dijelaskan pada paragraph sebelumnya. Sistem kontrol kualitas air pada unit budidaya (ember) dapat dilihat pada Gambar 2.

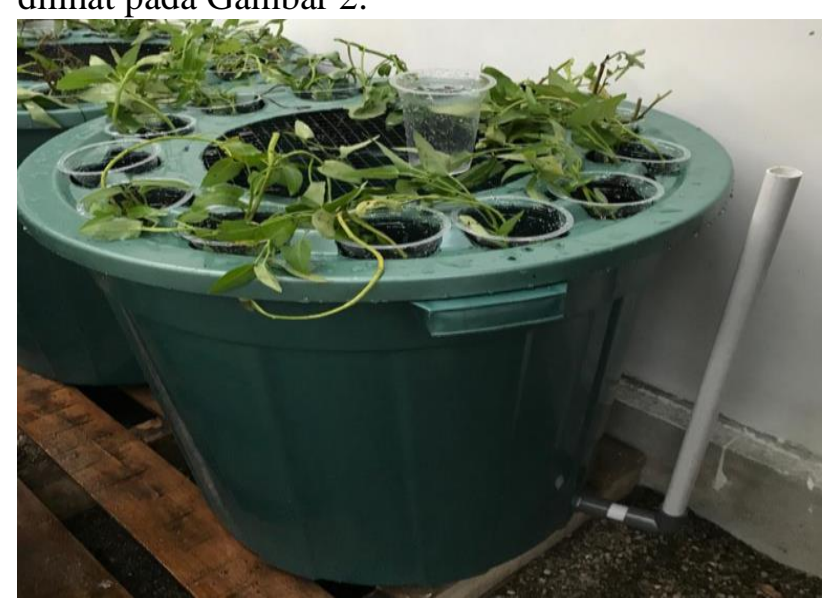

Gambar 2. Sarana budidaya ikan menggunakan wadah ember

Manajemen kualitas air pada media budidaya ikan harus dilkaukan dengan tepat. Haltersebut agar keberhasilan kegiatan budidaya ikan dapat tercapai. Karimah et al., (2018) menyatakan bahwa pertumbuhan ikan dipengaruhi oleh dua faktor yaitu faktor internal dan faktor eksternal. Faktor internal adalah faktor yang berkaitan dengan kondisi internal ikan, yaitu keturunan, jenis kelamin, dan usia. Faktor eksternal adalah faktor yang berkaitan dengan kondisi eksternal ikan yaitu kualitas air dan pakan. Scabra dan Budiardi (2020), memberikan contoh salah satu faktor eksternal, yaitu oksigen terlarut. Pada penelitian yang dilakukannya, kadar oksigen terlarut pada media budidaya ikan sidat sangat mempengaruhi pertumbuhan dari ikan sidta tersebut. Dalam kondisi kadar oksigen terlarut yang baik, pertumbuhan ikan sidta menjadi maksimal. Pada penelitiannya yang lain, Scabra dan Budiardi (2019) juga menjelaskan bahwa nilai salinitas merupakan salah satu bagian dari faktor faktor 
eksternal yang berpengaruh terhadap pertumbuhan ikan. Salinitas yang tepat dapat memniminalkan kejra osmoregulasi sehingga energi yang dihasilkan melalaui metabolisme ikan dpaat dimaksimalkan untuk keperluan bertumbuh.

Upaya lain yang dilakukan untuk menjaga kualitas air sebagai media budidaya ikan adalah dengan memelihara tanaman kangkung pada bagian atas wadah pemeliharaan ikan. Akar tanaman kangkung mengambil unsur hara berupa nitrogen yang merupakan limbah organik yang berasal dari sisa pakan atau hasil metabolisme ikan yang dipelihara. Sistem tersebut dikenal dengan istilah aquaponik (Hakim dan Hariadi, 2021). Setyono dan Scabra (2019), menytakan bahwa aktifitas budidaya ikan yang dibarengi dengan aktifitas budidaya tanaman (sayur) dapat memberikan keuntungan tersendiri. Teknologi akuaponik mempunyai lainnya berupa adanya pemasukan tambahan dari hasil tanaman yang akan memperbesar keuntungan para peternak ikan.

Panen ikan pada sistem budidaya menggunakan ember dapat dilakukan dalam kurun waktu 2-3 bulan pasca pemeliharaan dimulai. Jangka waktu tersebut dapat terjadi apabila bibit awal ikan lele yang digunakan memiliki ukuran yang berkisar antara 5-7 gram/ekor. Nasrudin (2010), menyatakan bahwa ukuran panen pada kegiatan ikan lele dapat dilakukan apabila ikan lele telah mencapai bobot 150-200 g/ekor. Pada bobot tersebut, jumlah ikan lele per kg mencapai 6-10 ekor. Waktu yang diperlukan untuk mencapai hal tersebut adalah 60-90 hari. Selama masa pemeliharaan, ikan yang berukuran lebih besar dapat dipanen terlebih dahulu. Ikan yang berukuran lebih kecil dapat dipanen belakangan sesuai dengan kebutuhan. Kapasitas panen ikan dengan menggunakan wadah berupa ember berukuran 150 liter dan kepadatan ikan sejumlah 100 ekor adalah $18 \mathrm{~kg}$. Pad akondisi tersebut, nilai SR ikan mencapai angka $90 \%$ dan bobot panen masingmasing ikan adalah 200 gram

\section{Kesimpulan}

Berdasarakan kegiatan yang telah dilakukan, kesimpulan dari kegiatan pengabdian kepada masyarakat ini adalah telah disampaikannya informasi, pengetahuan, dan bimbingan tekhnis kepada mitra tentang tekhnologi budidaya ikan dalam ember (budikdamber). Manajemen pengelolaan pada kegiatan budikdamber tersebut meliputi tahapan persiapan, tekhnis perakitan perangkat budidaya ikan, manajemen pemberian pakan, manajemen kualitas air, dan manajemen panen. Kegiatan ini perlu dilakukan secara konsisten yang melibatkan masyarakat yang lebih luas. Apabila masing-masing rumah pada suatu lingkungan tertentu dapat memiliki sebuah unit budidaya ikan menggunakanw adah ember, maka minimal kebutuha konsumsi ikan segar harian pada lingkungan rumah tersebut dapat terpenuhi secara mandiri.

\section{Daftar Pustaka}

Astisela, P. D. (2019). Gambaran Pengetahuan Gizi dan Pola Konsumsi Ikan Pada Siswa SMA Negeri 1 Padang Cermin Tahun 2019 [skripsi]. Lampung (ID) : Poltekkes Tanjungkarang.

Habiburrohman, H. (2018). Aplikasi Teknologi Akuaponik Sederhana Pada Budidaya Ikan Air Tawar Untuk Optimalisasi Pertumbuhan Tanaman Sawi (Brassica Juncea L.) [skripsi]. Lampung (ID) : UIN Raden Intan.

Hakim, R. R., \& Hariyadi. 2021. Teknologi Akuaponik sebagai Solusi Kemandirian Pangan Keluarga di Kelompok Kampung Wolulas Kecamatan Turen Kabupaten Malang. Amalee Indonesian Journal of Community Research and Engagement, 2 (1):43-52.

https://doi.org/10.37680/amalee.v2i1.643

Inara, C. 2020. Manfaat Asupan Gizi Ikan Laut Untuk Mencegah Penyakit dan Menjaga Kesehatan Tubuh Bagi Masyarakat Pesisir. Jurnal Kalwedo Sains, 1 (2) : 9295.

Karimah, U., Samidjan, I., \& Pinandoyo. 2018. Performa Pertumbuhan Dan Kelulushidupan Ikan Nila Gift (Oreochromis Niloticus) Yang Diberi Jumlah Pakan Yang Berbeda. Journal of Aquaculture Management and Technology, 7 (1) : 128-135. 
$\underline{\text { http://ejournal- }}$

s1.undip.ac.id/index.php/jamt

Milo, M. S. (2013). Mutu Ikan Tongkol (Euthynnus affinis C.) di Kabupaten Gunungkidul Dan Sleman Daerah Istimewa Yogyakarta [skripsi]. Jogjakarta (ID) : Universitas Atma Jaya.

Nasrudin. 2010. Jurus Sukses Beternak Lele Sangkuriang. Jakarta (ID) : PT Penebar Swadaya.

Nursani, J. 2018. Budidaya Ikan Dalam Ember "Budikdamber" dengan Aquaponik di Lahan Sempit. Prosiding Seminar Nasional Pengembangan Teknologi Pertanian : 129-136. http://jurnal.polinela.ac.id/index.php/PR OSIDING

Scabra, A. R., \& Budiardi, T. (2019). Respon Ikan Sidat Anguilla Bicolor Bicolor Terhadap Media Dengan Salinitas Berbeda. Jurnal Perikanan, 9 (2) : 180187. https://doi.org/10.29303/jp.v9i2.167

Scabra, A. R., \& Budiardi, T. (2020). Optimization of Anguilla bicolor oxygen consumption in alkalinity culture media. Indonesian Journal of Tropical Aquatic, 3 (1) : 7-13. https://doi.org/10.22219/ijota.v3i1.12361

Scabra, A. R., Wahyudi, R., \& Rozi, F. 2021. Introduksi Teknologi Budidaya Ikan Dalam Ember (Budikdamber) di Desa Gondang Kabupaten Lombok Utara. Jurnal Pengabdian Perikanan Indonesia, 1 171-179. http://doi.org/10.29303/jppi.v1i2.187

Scabra, A.R., \& Setyowati, D.N. 2019. Peningkatan mutu kualitas air untuk pembudidaya ikan air tawar di Desa Gegerung Kabupaten Lombok Barat. Abdi Insani Universitas Mataram, 6 (2), 267-275.

https://doi.org/10.29303/abdiinsani.v6i2. $\underline{243}$

Setyono, B.D.H., \& Scabra, A.R., (2019). Teknologi Akuaponik Apung Terintegrasi Budidaya Ikan Nila Di Desa Kapu Kabupaten Lombok Utara. Abdi
Insani Universitas Mataram, 6 (2), 199. 205.

http://doi.org/10.29303/abdiinsani.v6i2.2 $\underline{41}$

Suprayitno, E. 2020. Kajian Kesegaran Ikan Di Pasar Tradisional Dan Modern Kota Malang. Journal of Fisheries and Marine Research, 4 (2) : 289-295.

Tahaparih, E., \& Suhenda, N. Penentuan Frekuensi Pemberian Pakan Untuk Mendukung Pertumbuhan Benihikan Patin Pasupati. Berita Blologi, 9 (6) : 693-698

Ubadillah, A., \& Hersoelistyorini, W. 2010. Kadar Protein Dan Sifat Organoleptik Nugget Rajungan Dengan Substitusi Ikan Lele (Clarias gariepinus). Jurnal Pangan dan Gizi, 1 (2) : 45-54.

Widowati, R. 2008. Keberadaan Bakteri Vibrio Parahaemolyticus Pada Udang Yang Dijual Di Rumah Makan Kawasan Pantai Pangandaran. Vis Vitalis, 1 (1) : 9-14. 